\title{
Hepatitis B virus surface antigen (HBsAg) and antibody (anti-HBs) forming immune complexes in fulminant hepatitis
}

\author{
Antígeno de superfície do vírus da hepatite B (HBsAg) e anticorpo (anti-HBs) \\ formando imunocomplexos em hepatite fulminante
}

\author{
Manoel C.P. Soares, Gilberta Bensabath, Paulo R.B. Cartágenes, Max M. Alves, \\ Fernando A.A. Silveira and Alexandre C. Linhares
}

\begin{abstract}
This paper reports an unusual pattern of serological HBV markers and the presence of HBsAg/anti-HBs immune complexes in serum samples from two patients with fulminant hepatitis from the Brazilian Western Amazon Basin. The diagnosis was made by both serologic tests and demonstration of antigen/antibody complexes by transmission electron microscopy. Concurrent Delta virus superinfection is also discussed.
\end{abstract}

Key-words: Fulminant hepatitis. Hepatitis B. Hepatitis D. Immune complexes.

Resumo Este trabalho relata um padrão sorológico não usual para o HBV e a presença de imunocomplexos HBsAg/anti-HBs em amostras de soro provenientes de dois pacientes com hepatite fulminante procedentes da Amazônia Ocidental Brasileira. O diagnóstico foi estabelecido por meio de testes sorológicos e pela demonstração de complexos antígeno/anticorpo por técnicas de microscopia eletrônica de transmissão. A concomitante superinfecção pelo vírus da hepatite Delta também é discutida.

Palavras-chaves: Hepatite fulminante. Hepatite B. Hepatite D. Imunocomplexos.

One of the main characteristics of hepatitis $B$ virus (HBV) is its antigenic heterogeneity. AntiHBs, an antibody homologous to HBsAg, represents the major neutralizing antibody protecting against infection by this viral agent. In fact, anti-HBs reflects immunity against HBV infection. Thus, in principle, HBsAg and anti-HBs would not be expected to be present concomitantly in the same serum sample.

The aim of this study was to investigate by electron microscopy (EM) the apparently uncommon concomitant serological detection of $\mathrm{HBsAg}$ and anti-HBs in patients with fulminant hepatitis from two States of the Brazilian Western Amazon region, where fulminant hepatitis caused by hepatitis $B$ and $D$ viruses represents a major public health hazard 23 . In an attempt to explain these findings, three possibilities were raised: a) the detection of a possible false-positive serological reaction, b) the lack of homology between the antigen ( $\mathrm{HBsAg})$ and the antibody (anti-HBs), or c) the unusual simultaneous occurrence of both antigen and antibody during the disease.

Sera were obtained from two patients living in the rural area of Acre and Amazonas States, Brazil, who died of fulminant hepatitis (Table 1). The serum samples were tested by ELISA for the presence of viral hepatitis markers and the following results were obtained: patient 1 was $\mathrm{HBsAg}$ and anti-HBs positive, anti-HBc IgM

Instituto Evandro Chagas, Fundação Nacional de Saúde do Ministério da Saúde, Belém, PA, Brasil.

Address to: Dr. Manoel C.P. Soares. Av. Almirante Barroso 492, 66090-000 Belém, PA, Brasil.

Tel: 5591 211-4461; Fax: 5591 226-1284.

Recebido para publicação em 13/2/98. 
Table 1 - Characteristics of two patients who died from fulminant hepatitis, Brazilian Western Amazon, 1997.

\begin{tabular}{lcccl}
\hline Identification & Sex & Age $(\mathrm{y})$ & Symptons onset (days) & Residence \\
\hline Patient 1 & $\mathrm{f}$ & 11 & 4 & Sena Madureira/AC \\
Patient 2 & $\mathrm{m}$ & 11 & 6 & Pauini/AM \\
\hline
\end{tabular}

$\overline{\mathrm{AC}}=$ Acre State $; \mathrm{AM}=$ Amazonas State

negative, HDAg positive, and anti-HD and anti$\mathrm{HCV}$ negative, and patient 2 was $\mathrm{HBsAg}$ and anti-HBs positive, and anti-HBc IgM, HDAg, anti-HD and anti-HCV negative. Only liver tissue from patient 2 was submitted to histology, which showed a histopathologic picture of microvesicular steatosis resulting in characteristic morula cells2 3 (Figure 1).

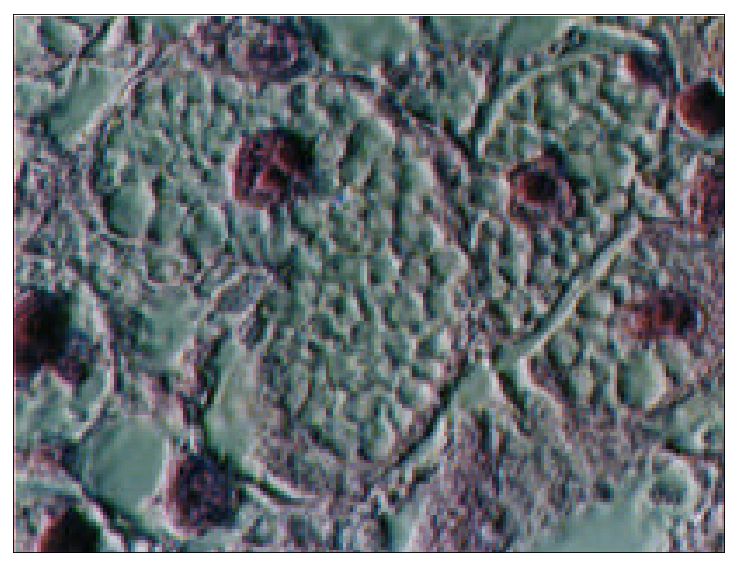

Figure 1 - Histopathologic picture of the liver from patient 2: microvesicular steatosis resulting in characteristic morula cells (HE stain and diferential interference contrast). $x 450$.

Briefly, the EM technique used was as follows: $0.2 \mathrm{ml}$ of the serum samples were diluted in $0.2 \mathrm{ml}$ of distilled water and centrifuged at 15,000rpm for one hour. The supernatant was discarded and the original volume was subsequently reconstituted with distilled water and centrifuged as before. The second pellet was then resuspended in $0.05 \mathrm{ml}$ of distilled water and counter-stained with $1 \%$ phosphotungstic acid, $\mathrm{pH}$ 7.2. This preparation was examined by transmission electron microscopy (Zeiss 900).

Typical aggregates of HBsAg/anti-HBs were visualized in both serum sample preparations, involving round particles with a mean diameter of $21.6 \mathrm{~nm}$, as calculated by measuring 30 particles (Figure 2). An excess of antibody was observed in these clumps, but, interestingly, only round HBsAg particles were identified forming immune complexes and no Dane particles could be seen.

A major finding of this study was the confirmation by EM of the results previously obtained by serology. The simultaneous detection

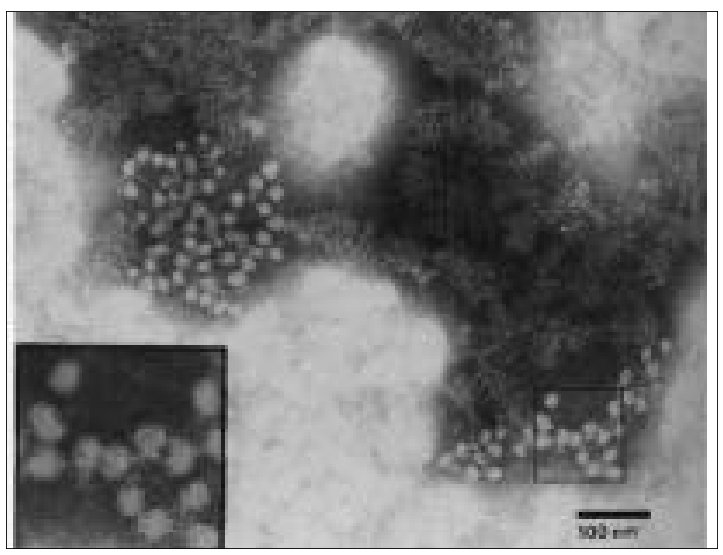

Figure 2 - Antibody coated HBsAg particles making immune complexes. Details in the inset. Observe antibody excess.

of HBsAg and anti-HBs forming immune complexes in both patients may be of potential importance regarding the pathogenesis of fulminant hepatitis in the Amazon region, and deserves further investigation. It should be pointed out that some authors have associated the occurrence of severe hepatitis in chronic HBsAgcarriers with simultaneous or subsequent production of anti-HBs 45 . Sometimes immune complex formation was observed in sera from HBsAg-positive patients with fulminant hepatitis 17. The peculiar ultrastructural aspects observed in this study were similar to those observed by Almeida and Waterson (1969) in a case of fulminant hepatitis 1 . In addition, recent 
experiments have shown that the induction of vaccine antibodies (anti-WHs) in animals which are chronic carriers of WHV - a hepadnavirus from the American woodchuck - may result in fulminant hepatitis 4 .

In one of the patients the laboratory results indicated the occurrence of HDV superinfection. Such concurrent infections may result in fulminant hepatitis, in which the suppression of HBV replication by HDV has been suggested to occur and decreased levels of HBsAg antigenemia have been observed 56 . The peculiar alteration of the hepatocytes in patient 2 - microvesicular steatosis with a morula cell aspect - has been frequent in victims of fulminant hepatitis from the Brazilian Western Amazon Basin?.
Only one patient reported previous hepatitis $B$ vaccination; however, HDV superinfection itself suggests a new HBV antigens contact. On the other hand, hepatitis $B$ vaccination studies in that area showed no important adverse reactions ( $G$ Bensabath, MCP Soares: unpublished observation).

Further studies on this subject should possibly address questions which remain to be clarified such as: a) would the decrease in $\mathrm{HBsAg}$ levels during fulminant hepatitis B or D be associated with the formation of serum immune complexes? and b) would the induction of anti-HBs formation have any importance regarding the pathogenesis of fulminant hepatitis in chronic HBsAg-carriers?

\section{REFERENCES}

1. Almeida JD, Waterson AP. Immune complexes in hepatitis. The Lancet 8:983-986, 1969.

2. Bensabath G, Hadler SC, Pereira Soares MC, Fields H, Dias LB, Popper H, Maynard JE. Hepatitis delta virus infection and labrea hepatitis - prevalence and role fulminant hepatitis in the Amazon basin. Journal of the American Medical Association 258:479-483, 1987.

3. Fonseca JCF, Ferreira LCL, Guerra ALPS, Passos LM, Simonetti JP. Hepatite fulminante e febre negra de lábrea: estudo de 5 casos procedentes de Codajás, Amazonas, Brasil. Revista da Sociedade Brasileira de Medicina Tropical 16:144-147, 1983.

4. Hervas-Stubbs S, Lasart J, Sarobe P, Cullen J, Roggendorf M, Borrás-Cuesta F. Therapeutic vaccination of woodchucks against chronic woodchuck hepatitis virus infection. Journal of Hepatology 27: 726-737, 1997.

5. Moestrup T, Hansson BG, Widell A, Nordenfelt E. Clinical aspects of delta infection. British Medical Journal 286: 87-90, 1983.

6. Rizzetto M, Canense MG, Gerin JL, London WT, Sly $\mathrm{DL}$, Purcell RH. Transmission of hepatitis B virus Associated delta antigen to chimpanzees. The Journal of Infectious Diseases 121:590-602, 1980.

7. Woolf IL, El Sheikh N, Cullens H, Lee WM, Edleston ALWF, Williams R, Zuckerman AJ. Enhanced HBsAb production in pathogenesis of fulminant viral hepatitis type B. British Medical Journal 2:669-671, 1976. 